\title{
Factors of non-specific immunodefence of American mink of Scandinavian selection during acclimatization to domestic conditions of growing
}

\section{O. Verbova}

\author{
National Academy of Agrarian Sciences of Ukraine
}

The purpose. To determine the level of activity of cell (phagocytosis) and humoral (level of activity of a complement and lysozyme) factors of non-specific immunodefence of American mink of Scandinavian selection during acclimatization to domestic conditions of growing. Methods. Cell factors of non-specific immunodefence were determined according to phagocytic coefficients of blood, humoral ones - according to the level of activity in blood serum of a complement and lysozyme. Test data reduction was carried out using the method of mathematical statistics. Reliability of differences of average values was evaluated by means of Student t-test number. Results. Biochemical researches were carried out of blood cell and humoral factors of non-specific (natural) immunodefence of young animals of American mink of 4 color types (Scanbrown, Scanblack, Sapphire and Pearl) which were in conditions of acclimatization, and statistical analysis of the gained data. Conclusions. The obtained data allowed forecasting reproductive ability of American mink of Scandinavian selection in conditions of domestic farms.

Key words: American mink, color type, Scandinavian selection, non-specific immunodefence, acclimatization.

At present, in the ukrainian farms which are engaged at the American mink cultivation, a part of the livestock is constantly imported and is in the process of adaptation to the conditions of abstinence and feeding. Highly productive short-haired mink Scandinavian breeding (Scanbrown, Scanblack, Sapphire, Pearl, etc.) continues to be imported. [8-11]. The reproductive capacity of imported animals in the conditions of domestic farms is lower than the potential one. Studying the mechanisms of adaptation processes in the mink of Scandinavian breeding will enable to predict the reproductive ability of the American mink Scandinavian breeding in the conditions of domestic farms and increase the number of animals with a greater reproductive capacity $[4-8,13]$.

Adaptive reaction is a nonspecific (natural) immunity of the animals, which is the result of the combined action of a number of non-specific cell and humoral factors. A non-specific immunity cellular link is provided by phagocytosis, among complementary, lysozyme and beta-lysine of serum [1-7] play an important role in humoral matters.

The research purpose is to determine the level of cell activity (phagocytosis) and humoral (complement activity and lysozyme) factors of the nonspecific immunity of the American mink of the Scandinavian selection in the process of adaptation to the domestic animal welfare.

The research materials and methods: the experiment was conducted in groups of 10 females of the 6month-old age of four colored American mink types: Scanbrown, Scanblack, Sapphire and Pearl, which were in the process of adaptation at the Ltd. "Fur farm Zolotoniske" (Kedina Gora village, Zolotoniski district, Cherkasy region). All animals were kept in open-air enclosures.

Biochemical studies of blood of cell and humoral factors of nonspecific (natural) animal immunity were carried out and a statistical analysis of the data was obtained. Samples of blood were taken in the morning until the first feeding of the caudal vein of animals.

The cellular factors of non-specific immunity were determined by phagocytic blood parameters (the V.M. Berman's and Y.M. Slavskaya method, 1958), and humoral ones - by the level of activity in serum of lysozyme blood (V.G. Dorofeichuk, 1968) and complement (G.F. Wagner, 1963, A.V. Gustov, 1971). 
Research results.

The first factor of natural resistance studied - phagocytosis - is one of the most important antimicrobial barriers, whose indicators are a sensitive indicator of the body's condition. Increased activity of phagocytosis is observed in bacterial and viral diseases, decrease - in purulent-septic processes, complicated and protracted infections, as well as in anemia, starvation, deficiency disease, ionizing radiation, and the like. [4$7,13]$.

The phagocytic activity level - the neutrophil cells percentage that are involved in the active capture and absorption of microbial cells - is given in Table 1.

Table 1. Phagocytosis activity level,\%

\begin{tabular}{|c|c|c|c|c|}
\hline Color type & $\mathbf{n}$ & $M \pm m$ & $\lim$ & C.V., \% \\
\hline Scanbrown & 10 & $26,60 \pm 3,06^{*}$ & $16-48$ & 36,33 \\
\hline Scanblack & 10 & $29,90 \pm 2,70^{*}$ & $10-44$ & 28,57 \\
\hline Sapphire & 10 & $32,60 \pm 2,60$ & $20-48$ & 25,26 \\
\hline Pearl & 10 & $22,30 \pm 2,16^{* *}$ & $14-36$ & 30,64 \\
\hline Standard dark brown ${ }^{1)}$ & 10 & $39,09 \pm 2,75$ & $27-50$ & 22,28 \\
\hline
\end{tabular}

1) according to V.A. Berestov (1981), ${ }^{*}-\mathrm{P}>0,95,{ }^{* *}-\mathrm{P}>0,99$

The research results were compared with the data V.A. Berestov, obtained in 1981, about the standard dark-brown type mink, which was traditionally bred in Ukraine [4].

The highest average value for this indicator was in the Sapphire group mink. The smallest difference in this indicator compared to standard dark brown mink (only 6.46\%) was in the Sapphire-type murmur. In the remaining color types, this indicator was significantly lower than standard dark brown mink ( $P>0.95 \ldots 0.99)$ and varied within $22.3-29.9 \%$. The lowest value of this indicator was registered in the Pearl type. The mites of the Scanbrown and Scanblack types had a slight difference in this indicator.

The average number of phagocyte microbial cells per phagocytosis (phagocyte count) is given in Table 2 . Mice of imported genotypes have, in all cases, the highest rates of standard dark brown mink ( $P>0.999)$. The highest value for this indicator was recorded in the Scarecrows type, the worst one is in the Pearltype.

Table 2. Phagocytic number

\begin{tabular}{|c|c|c|c|c|}
\hline Color type & $\mathbf{n}$ & $M \pm m$ & $\lim$ & C.V.,\% \\
\hline Scanbrown & 10 & $5,30 \pm 0,31^{* * *}$ & $4,0-7,0$ & 18,68 \\
\hline Scanblack & 10 & $7,40 \pm 0,55^{\star * *}$ & $5,2-11,4$ & 23,46 \\
\hline Sapphire & 10 & $6,95 \pm 0,46^{* * *}$ & $4,4-9,0$ & 20,83 \\
\hline Pearl & 10 & $4,95 \pm 0,24^{\star * *}$ & $3,8-6,0$ & 16,83 \\
\hline Standard dark brown ${ }^{1)}$ & 10 & $2,07 \pm 0,09$ & $1,7-2,7$ & 13,38 \\
\hline
\end{tabular}

1) according to V.A. Berestov (1981), ${ }^{* * *}-\mathrm{P}>0,999$.

The second factor of natural resistance was the lysozyme activity level. Lysozyme is a substance of protein nature, a hydrolytic enzyme of the hydrolase group, which cleaves high molecular weight polysaccharides of bacterial cells, has a bactericidal effect on many gram-positive and some gram-negative microorganisms [4-8]. Lysozyme activity indicators in serum of the studied mink are represented in Table 3. 
Table 3. Lysozyme activity level in serum of mink blood,\%

\begin{tabular}{|c|c|l|l|l|l|}
\hline Color type & $\boldsymbol{n}$ & $\boldsymbol{M} \pm \boldsymbol{m}$ & $\operatorname{Lim}$ & $\boldsymbol{\sigma}$ & $\boldsymbol{C . V}, \boldsymbol{\%}$ \\
\hline Scanbrown & 10 & $0,35 \pm 0,02$ & $0,23-0,45$ & 0,07 & 21,04 \\
\hline Scanblack & 10 & $0,41 \pm 0,03$ & $0,27-0,50$ & 0,08 & 19,75 \\
\hline Sapphire & 10 & $0,37 \pm 0,02$ & $0,31-0,50$ & 0,06 & 15,79 \\
\hline Pearl & 10 & $0,35 \pm 0,04$ & $0,22-0,60$ & 0,12 & 35,30 \\
\hline $\begin{array}{c}\text { Standard dark } \\
\text { brown }\end{array}$ & 10 & $0,93 \pm 0,04$ & $0,78-1,25$ & 0,15 & 16,10 \\
\hline
\end{tabular}

* according to V. A. Berestov, G. M. Malynina (1991).

The lysozyme activity highest level was observed in black scabies Scanblack - $0.41 \%$, lowest - in brown scanbrown and beige Pearl (0.35\%).

According to many years' research of V.A. Beresta's mean value of lysozyme activity in standard dark brown mink is $0.93 \%$ [6]. When comparing the average figures in imported animals of all types of coloration with the average indicators of females at standard dark brown type, the probable difference between these indices was not detected $(P<0,95)$.

The lysozyme activity lower level at Scandinavian breeder mites, which are in adaptation conditions, in comparison with mumps of the standard dark brown type, which were kept under their usual conditions, testify to the high activity of the immune system of the first under the action of paratyphoid factors.

The next researched indicator is the activity level of the complement. Complement - a complicated protein complex of globulin nature, present in fresh blood serum, lymph and tissue fluids of the body, which participates in the immune response of the body, performing various functions: responds to the corpuscular antigens lysis (microbes, red blood cells), accelerates phagocytosis, participates in virus neutralization, effects on precipitation test and agglutination. The complement content in the blood serum of mink is considered one of the most objective indicators of the state of non-specific protection in animal organism [48]. The level of complement activity is shown in Table 4.

Table 4. Complement activity level in serum of mare blood, unit/ml

\begin{tabular}{|l|l|l|l|l|l|}
\hline Color type & $\mathbf{n}$ & $\mathbf{M} \mathbf{m}$ & $\mathbf{L i m}$ & $\boldsymbol{\sigma}$ & $\mathbf{C . V}, \%$ \\
\hline Scanbrown & 10 & $63,10 \pm 17,10$ & $20-160$ & 54,09 & 85,72 \\
\hline Scanblack & 10 & $103,80 \pm 20,20$ & $40-199$ & 63,87 & 61,53 \\
\hline Sapphire & 10 & $105,31 \pm 14,67$ & $20-166$ & 46,38 & 44,04 \\
\hline Pearl & 10 & $110,50 \pm 17,59$ & $20-199$ & 55,64 & 50,35 \\
\hline $\begin{array}{l}\text { Standard dark } \\
\text { brown* }\end{array}$ & 10 & $27,56 \pm 0,96$ & $22-31$ & 2,72 & 9,86 \\
\hline
\end{tabular}

${ }^{*}$ according to V. A. Berestov, G. M. Malynina (1991).

The highest level of the complement activity in the mink bloods of Scandinavian breeding was found in females of Pearl type - 110.50 units $/ \mathrm{ml}$; the smallest - in Scanbrown females - 63.10 units $/ \mathrm{ml}$. When comparing the averages, the difference between these indicators was unlikely $(P<0,95)$.

According to V.A. Berestova and GM Malinin's the mean value of the activity level of the complement in the standard dark brown type is 27.6 units $/ \mathrm{ml}$. [6]. When comparing the average values of the indicator in the standard dark brown type mink with the average scorecard scanbrown and Scanblack types, a probable 
difference was detected ( $P>0.99)$; when compared with mink Sapphire and Pearl types, the difference was highly probable $(R>0,999)$.

The elevated complement level indicates that mink Scandinavian breeding in adaptation conditions is more responsive to aggressive environmental factors than mosquitoes of the standard dark brown type under the usual conditions.

\section{Conclusions}

Indicators of the resistance level of the American mink Scandinavian breeding, which are in adaptation, indicate the high activity of their immune system under the influence of paratypic factors.

The Scandinavian selection mites, which are in the process of adaptation, react more acutely to external factors than standard dark brown, which are in normal conditions.

Moles of various color types of Scandinavian breeding in the process of adaptation respond differently to environmental factors.

The obtained data will enable to predict the reproductive capacity of the American mink Scandinavian breeding in the conditions of domestic farms.

\section{References}

1. Abramov M. D. The breeding of the mink / M. D. Abramov. - M., Selhozgiz, 1971. - $77 \mathrm{p}$.

2. Balakirev N. A. Fundamentals of Nordic Studies / N. A. Balakirev. - M .: Vyssh. Shk., 2001. - $278 p$.

3. Balakirev N. A. Contents of fur animals in modern conditions / N. A. Balakirev, I. V. Parkalov. - SPb .: Peter, 2008. - $31 \mathrm{p}$.

4. Berestov V.A. Laboratory methods for assessing the condition of fur animals. - Petrozavodsk: Karelia, 1981. $151 \mathrm{p}$.

5. Berestov V.A. Laboratory methods for assessing the quality of feed in fur farming / VA Berestov, G.S. Taranov - Petrozavodsk, 1983.-80 p.

6. Berestov V.A. Special features of non-specific immunity in mink and foxes / VA Berestov, G. M. Malinin. - L.: "Science", 1991 - 203 p.

7. Berestov V.A. Alcoholism: A manual / VA Berestov. - SPb .: "Lan", 2002. - 182-189 p.

8. Gonchar O. F., Gavrish O. M. Reproductive ability of mink: Monograph - Cherkasy: Chornobaivskoe municipal polygraphic enterprise, 2010. - $264 \mathrm{p}$.

9. Gonchar O. F. Dynamics of Growth and Development of Young Shoots of Scandinavian Selection in Different Maintenance Systems / O. F. Gonchar, O. M. Gavrish, N. V. Yaremich // Effective rabbit and animal husbandry. - 2016 - №1.

10. Gonchar O. F. The level of conservatism of the young mammals of Scandinavian breeding in the conditions of adaptation reactions to breeding in domestic farms / Gonchar O. F., Gavrish O. M., Yaremich N.V. // Effective rabbit and animal husbandry. - 2016 - №1.

11. Gonchar O.F. Ways of increasing the reproductive capacity of American mink (methodical recommendations)/Gonchar O. F., Gavrish O. M., Ryasenko E. Cherkassy: FOP Bedenko V. P., 2009. 32 p.

12. Scientific basis of breeding / ed. V.A. Berestov. - L.: Nauka, 1985. - 477 pp.

13. Nigmatullin R. M. The effect of natural selection in rabbits and mink in the natal period / Nigmatullin R.M. // Vestnik VOGiC. - 2007. - T. 11, No. 3.4. - P. 657-661.

14. Essays on the physiology of fur animals, ed. V.A. Berestov. - L.: Nauka, 1987. - 239 p. 